\title{
Screening of Sorghum Genotypes against Charcoal Rot caused by Macrophomina phaseolina (Tassi) Goid.
}

\author{
S. N. Chattannavar ${ }^{1}$ and Vinayaka A. Bannur ${ }^{2 *}$
}

${ }^{1}$ All India Coordinated Sorghum Improvement Project, Dharwad, India

${ }^{2}$ Department of Plant Pathology, College of Agriculture, Dharwad, India

University of Agricultural Sciences, Dharwad, Karnataka, India-580005

*Corresponding author

\section{A B S T R A C T}

\section{Keywords}

Sorghum, Charcoal rot, Macrophomina phaseolina

Article Info

Accepted:

18 March 2020

Available Online:

10 April 2020
Twenty-three genotypes were screened for charcoal rot resistance in the sick plot during rabi 2018-19. The results of the study indicated that the genotypes E 36-1 (12.00) followed by SPH 1903, SPV 2654, SPV 2655, SPV 2656 and CSH 13R (13.00) showed minimum charcoal rot index compared to other genotypes. Highest charcoal rot index was recorded in SPV 2662 (31.00) followed by Phule Anuradha (29.00). Out of twentythree genotypes screened twenty-one genotypes showed moderately resistant reaction and remaining two genotypes showed susceptible disease reaction

\section{Introduction}

Sorghum [Sorghum bicolor (Linn.) Moench] has occupied an area of 56 lakh hectares with the production of 46 lakh tons and productivity of $812 \mathrm{~kg} / \mathrm{ha}$. The major sorghum cultivating states are Maharashtra, Karnataka, Rajasthan, Tamil Nadu and Andhra Pradesh. It is being grown in two seasons: kharif season as a rainfed crop while in rabi season under remaining soil moisture conditions. In Karnataka, it is cultivated on 10.90 lakh hectares of which 1.16 lakh hectares in kharif and 9.74 lakh hectares in rabi with production and productivity of 11.50 lakh tons and 1,052 $\mathrm{kg} \mathrm{ha}{ }^{-1}$ respectively (Anon., 2017). The hunt for new varieties and hybrids with better productivity and resistance is a continuous process in crop improvement.

Charcoal rot disease has become a major production constraint in rabi sorghum. The indirect loss computed to this disease alone amounts to 40 per cent (Hiremath and Palakshappa, 1994). Patil (1980) reported that the loss in grain yield was more in rabi (40.83 
\%) than in kharif $(17.69 \%)$. The present study was carried out to screen twenty-three genotypes for charcoal rot resistance.

\section{Materials and Methods}

A field experiment was conducted at Main Agricultural Research Station, Dharwad in sick plot conditions during rabi 2018-19. Test genotypes were sown during the second fortnight of October with a spacing of $45 \mathrm{~cm}$ $\times 15 \mathrm{~cm}$ with three replications. The susceptible check, CSV 8R was sown after two test entries. Observations on charcoal rot incidence, mean length of spread $(\mathrm{cm})$, mean number of nodes crossed and charcoal rot index (CRI) were recorded for screening purpose.Charcoal rot percentage and mean length of spread of lesion were used for estimation of charcoal rot index (CRI) using the formula $(\mathrm{CRI}=\mathrm{CRP} \times 0.4+\mathrm{MLS} \times 0.6)$. Disease reaction of each genotype was determined following the CRI scales (Das et al., 2018).

\begin{tabular}{|c|l|}
\hline CRI VALUE & Disease Reaction \\
\hline $\mathbf{5}$ & Highly Resistant \\
\hline $\mathbf{6}-\mathbf{1 0}$ & Resistant \\
\hline $\mathbf{1 1}-\mathbf{2 5}$ & Moderately resistant \\
\hline $\mathbf{2 6}-\mathbf{4 0}$ & Susceptible \\
\hline$>\mathbf{4 0}$ & Highly susceptible \\
\hline
\end{tabular}

\section{Results and Discussion}

The results revealed that, charcoal rot index was least in E 36-1 (12.00) followed by SPH 1903, SPV 2654, SPV 2655, SPV 2656 and CSH 13R (13.00). Highest charcoal rot index was recorded in SPV 2662 (31.00) followed by Phule Anuradha (29.00) (Table 1).

Table.1 Field evaluation of sorghum genotypes against charcoal rot of sorghum

\begin{tabular}{|c|c|c|}
\hline Sl. No. & Genotype name & Charcoal rot index \\
\hline $\mathbf{1 .}$ & SPH 1902 & 20 \\
\hline $\mathbf{2 .}$ & SPH 1903 & 13 \\
\hline $\mathbf{3 .}$ & SPV 2562 & 16 \\
\hline $\mathbf{4 .}$ & SPV 2653 & 18 \\
\hline $\mathbf{5 .}$ & SPV 2654 & 13 \\
\hline $\mathbf{6 .}$ & SPV 2655 & 13 \\
\hline $\mathbf{7 .}$ & SPV 2656 & 13 \\
\hline $\mathbf{8 .}$ & SPV 2657 & 17 \\
\hline $\mathbf{9 .}$ & SPV 2658 & 19 \\
\hline $\mathbf{1 0 .}$ & SPV 2659 & 14 \\
\hline $\mathbf{1 1 .}$ & SPV 2660 & 17 \\
\hline $\mathbf{1 2 .}$ & SPV 2661 & 19 \\
\hline $\mathbf{1 3 .}$ & SPV 2662 & 31 \\
\hline $\mathbf{1 4 .}$ & SPV 2663 & 22 \\
\hline $\mathbf{1 5 .}$ & SPV 2664 & 16 \\
\hline $\mathbf{1 6 .}$ & CSH 13R & 13 \\
\hline $\mathbf{1 7 .}$ & CSH 15R & 22 \\
\hline $\mathbf{1 8 .}$ & CSV 26R & 15 \\
\hline $\mathbf{1 9 .}$ & M 35-1 & 18 \\
\hline $\mathbf{2 0 .}$ & Phule Anuradaha & 29 \\
\hline $\mathbf{2 1 .}$ & Phule Maulee & 14 \\
\hline $\mathbf{2 2 .}$ & Local Check & 21 \\
\hline $\mathbf{2 3 .}$ & E 36-1 & 12 \\
\hline & & \\
\hline
\end{tabular}


Table.2 Reaction of sorghum genotypes to charcoal rot

\begin{tabular}{|c|c|c|}
\hline $\begin{array}{c}\text { CRI } \\
\text { value }\end{array}$ & Genotypes & Disease reaction \\
\hline$<5$ & Nil & Highly resistant \\
\hline $5-10$ & Nil & Resistant \\
\hline $11-25$ & $\begin{array}{l}\text { SPH 1902, SPH 1903, SPV 2562, SPV } 2653 \text {, SPV 2654, SPV } \\
\text { 2655, SPV 2656, SPV 2657, SPV 2658, SPV 2659, SPV } \\
\text { 2660, SPV 2661, SPV 2663, SPV 2664, CSH 13R, CSH 15R, } \\
\text { CSV 26R, M 35-1, Phule Maulee, Local Check and E } 36-1\end{array}$ & $\begin{array}{l}\text { Moderately } \\
\text { resistant }\end{array}$ \\
\hline $26-40$ & SPV 2662 and Phule Anuradha & Susceptible \\
\hline$>40$ & Nil & $\begin{array}{c}\text { Highly } \\
\text { susceptible }\end{array}$ \\
\hline
\end{tabular}

Out of twenty-three genotypes screened against charcoal rot incidence in sick plot, none of the genotype showed highly resistant reaction and resistant reaction. Twenty-one genotypes showed moderately resistant reaction. Two genotypes showed susceptible disease reaction. None of the genotype showed highly susceptible reaction (Table 2).

The results of the screening were in accordance with studies made by Sukanya $e t$ al., (2017) who reported that the genotypes GS $23(15.50 \%)$ followed by GS $11(18.50$ $\%)$ and GS $22(19.00 \%)$ recorded least charcoal rot incidence compared to other genotypes. SPV 86 genotype recorded higher disease incidence $(48.00 \%)$.

Anahosur and Naik (1985) reported that susceptible genotypes possess less sugar content compared to resistant genotypes. Similarly, Nalawade et al., (2008) reported that resistant genotypes have more amount of sugar and phenolic compounds which confer resistant against the pathogen.

In this present study, this may be the reason for genotypes showing resistant and susceptible disease reaction. Thus, from the results it is clear that employment of newer resistance sources particularly SPH 1902 and SPH 1903 have shown resistance to charcoal rot over the years and can be effectively employed in resistance breeding programme against charcoal rot in sorghum.

\section{References}

Anahosur, K. H. and Naik, S. T., 1985, Relationships of sugar and phenols of root and stalk rot of sorghum with charcoal rot. Indian Phytopath., 38 (1): 131-134.

Anonymous., 2017, Selected state/seasonwise area, production and productivity of jowar in India. Ministry of Agriculture and Farmers' Welfare, Govt. of India, New Delhi, pp. 97-99.

Arora, M. and Dhurwe, U., 2014, Grain yield losses due to charcoal rot of sorghum infected by Macrophomina phaseolina. Global. J. Biol. Agri. Health. Sci., 3 (1): 267-269.

Das, I. K., Rakshit, S., Sharma, K. K., Chattannavar, S. N., Gholve, V. M., Jayalakshmi, S. K. and Tonapi, V. A., 2018, Development of a charcoal rot index for multilocation trials of sorghum. Crop Prot., 108: 102-109.

Hiremath, R. V. and Palakshappa, M. G., 1994, Severe incidence of charcoal rot of sorghum at Dharwad. Curr. Sci., 33: 44.

Nalawade, S. V., Agarkar, G. D. and 
Chirame, B. B., 2008, Biochemical mechanism of host resistance to Macrophomina phaseolina (Tassi) Goid. of sorghum. J. Maharashtra Agric. Univ., 33 (2): 193-195.

Patil, S. H., 1980, Studies on charcoal rot of sorghum caused by Macrophomina phaseolina (Tassi) Goid. M. Sc. (Agri.)
Thesis, Univ. of Agric. Sci., Bangalore, Karnataka (India).

Sukanya, R., Jayalakshmi, S. K. and Girish, G., 2017, Screening of sorghum genotypes against charcoal rot using tooth pick inoculation technique. Bioved, 28(1): 91-95.

\section{How to cite this article:}

Chattannavar, S. N. and Vinayaka A. Bannur. 2020. Screening of Sorghum Genotypes against Charcoal Rot caused by Macrophomina Phaseolina (Tassi) Goid. Int.J.Curr.Microbiol.App.Sci. 9(04): 2179-2182. doi: https://doi.org/10.20546/ijcmas.2020.904.260 